\title{
Plant and vegetation preferences for a high and a moderate yielding Norwegian dairy cattle breed grazing semi-natural mountain pastures
}

\author{
Nina Hovden SÆTHER ${ }^{\mathrm{a} *}$, Hanne SICKEL ${ }^{\mathrm{b}}$, Ann NORDERHAUG ${ }^{\mathrm{c}}$, Morten \\ SICKEL $^{\mathrm{d}}$, Odd VANGEN ${ }^{\mathrm{a}}$ \\ ${ }^{a}$ Department of Animal and Aquacultural Science, Norwegian University of Life Sciences, \\ PO Box 5003, 1432 Ås, Norway \\ ${ }^{\mathrm{b}}$ Royal Norwegian Society for Development, PO Box 115, 2026 Skjetten, Norway \\ ${ }^{\mathrm{c}}$ Norwegian Institute of Agricultural and Environmental Research, Kvithamar, 7500 Stjørdal, Norway \\ ${ }^{\mathrm{d}}$ Norwegian Radiation Protection Authority, Grini Næringspark 13, PO Box 55, 1332 Østerås, Norway
}

(Received 16 December 2004 - Accepted 30 June 2006)

\begin{abstract}
Plant and vegetation preferences of two Norwegian cattle breeds grazing semi-natural mountain pastures were studied for two weeks at two farms during one summer. Two rather different grazing sites gave the opportunity to study the two breeds at different pasture qualities, as well as to test if there is any interaction between breeds and study sites. Each of the two herds consisted of the old, moderate yielding Norwegian dairy breed Blacksided Trønder and Nordland Cattle (STN) and the modern, high yielding dairy breed Norwegian Red (NRF). In order to measure the plant preferences of the animals, faeces samples were collected and analysed for plant fragments. In addition, GPS-data showed the terrain chosen by the herds, and vegetation maps were drawn to find the connections between the grazed vegetation and plant preferences. The study shows that on nutrient and especially species rich vegetation growing on base and nutrient rich soil, as at the first study site (Skåbu), the plant species, plant genera and plant groups analysed for in the faeces samples indicate that both the STN and NRF breeds graze very much the same vegetation. However, the results from the second study site (Valdres), where the soil is less fertile, the plant species diversity is lower and the plant species distribution less uniform, the moderate yielding NRF breed seems to cover its higher nutritious requirements by grazing in areas with more nutrient rich vegetation compared to the lower yielding breed, STN.
\end{abstract}

grazing preferences / cattle / intensive and extensive breeds / pasture management / seminatural grasslands

Résumé - Préférences en termes de couvert végétal et d'espèces végétales des races bovines norvégiennes à forte production laitière ou modérée pâturant des prairies d'altitude seminaturelles. Les préférences alimentaires de deux races bovines norvégiennes pâturant des prairies

*Corresponding author: ninah@umb.no 
d'altitude semi-naturelles ont été étudiées durant deux semaines dans deux fermes pendant un été. Deux sites de pâturage ont permis d'étudier les deux races face à différentes qualités de pâturage et de tester une éventuelle interaction entre les races et les sites d'étude. Chacun des deux troupeaux comprenait des bovins laitiers de race Blacksided Trønder et Nordland (STN, race norvégienne ancienne avec une production laitière modérée) et des bovins de race Pie rouge (NRF, race prédominante en Norvège avec une production laitière élevée). Pour mesurer les préférences alimentaires des animaux au pâturage, des échantillons de fèces ont été collectés et analysés. En outre, les données GPS ont permis de localiser le site privilégié de pâture des animaux et la cartographie de la végétation a eu pour but de déterminer les relations existantes entre la végétation pâturée et la préférence des animaux pour certaines espèces végétales. Sur un couvert végétal riche en éléments nutritifs et particulièrement riche en espèces végétales se développant sur un sol basique et riche en nutriments, comme sur le premier site d'étude (Skåbu), les espèces, les genres et les familles de plantes détectées dans les échantillons de fèces indiquent que les races STN et NRF pâturent la même végétation. Sur le second site (Valdres), où le sol est moins fertile, la diversité des espèces est inférieure et la distribution des espèces est moins uniforme, la race NRF semble couvrir ses besoins nutritifs plus élevés en pâturant les secteurs où la végétation est nutritivement la plus riche comparativement à la race STN.

préférence au pâturage / bovin / élevage extensif et intensif / gestion du pâturage / prairies semi-naturelles

\section{INTRODUCTION}

Semi-natural grasslands are closely linked to transhumance (summer mountain farming) $[23,28]$. This livestock production system is characterised by continuity over centuries of traditional and extensive use, without cultivation of the grazing areas. The system creates some extremely species-rich, semi-natural grasslands. Due to transition to modern livestock production systems in Norway, with a strong decline in the utilisation of outlying land, the area of semi-natural grasslands has been reduced considerably during the last 50 years. This has led to extensive landscape changes [7, 29]. Large herbs have invaded abandoned grasslands, succeeded by shrubs and at last forests, and many of the semi-natural vegetation types characterising the grasslands have thus become highly threatened $[3,8,10,11,13,19]$. In Norway about $30 \%$ of the red list (threatened) species are declining due to the reduction of semi-natural vegetation types, especially old grasslands [9]. The former widespread, open grasslands now mostly remain as fragments, which still may be very species-rich [37]. Their continued existence and conservation value depend upon continued traditional use or special management measures. When managing these semi-natural grasslands, it is especially important to graze the entire area, since it consists of small-scale patches of different vegetation types within a single field. To maintain the biodiversity of seminatural grasslands it is therefore necessary to develop management methods taking this into account [28].

A survey conducted by Sæther and Vangen [40] revealed that farmers utilising the low yielding Norwegian dairy breed Blacksided Trønder and Nordland Cattle (STN) expected this breed to utilise extensive grasslands better than cows of the moderate yielding Norwegian Red (NRF) breed, without any further explanation of the expression "better". The results from a study by Auestad et al. (personal communication) comparing the grazing behaviour of NRF and the old native cattle breeds STN and Westland Fjord Cattle indicated that the old breeds spend more time grazing in undulating terrain than the modern breed (NRF).

Few studies have been performed to compare breeds with different production 
levels with regards to their plant and vegetation preferences in semi-natural grasslands. The review article by Rook and Tallowin [34] even claims that there is only anecdotal evidence for breed differences in dietary choice of grazing animals, but little experimental evidence, with genetic effects often confounded with background experience.

A simplified explanation of the resource allocation theory, launched by Beilhartz [4], implies that if the total available resources for an animal are constant, animals that are selected for higher production need to allocate more of their available resources to the increased production, at the expense of resources otherwise spent on less important fitness traits. The need to allocate the resources might only be compensated for by environmental factors to a certain extent. Several studies $[1,6,21,30,31,36]$ have shown that breeds and/or lines selected for high production intensity generally show lower levels of activity than breeds and lines not selected for the same high production intensity.

Differences in the level of activity linked to differences in genetic merits are the basis of the contra free loading phenomenon, described by Inglis et al. [20], Lindqvist et al. [25] and Schuts et al. [36]. The contra free loading phenomenon is defined as the animals' choice of difficult over easily accessible fodder. Lindqvist et al. [25] conclude that this difference might represent a genetically based difference in foraging strategy, since the low merit animals tend to choose the difficultly accessible fodder at a higher rate than the high merit animals. The referred studies were done on mice and poultry, and are relevant when studying differences in foraging strategy between two cattle breeds with different yielding levels, since they deal with relatively general behaviour patterns in animals.
On the basis of these theories and studies, this study addresses the following question: when grazing on extensive pastures (semi-natural mountain grasslands) where nutrient rich grazing plants are more spread over the area than on traditional cultivated grasslands, genetic high yielding cows will spend less energy walking around (= have lower level of activity) but focus more on finding the plant species and vegetation types that satisfy their hunger most efficiently than the genetic lower yielding cows.

\section{MATERIALS AND METHODS}

\subsection{Breeds and herds}

The two breeds in this study were Norwegian Red (NRF) and Blacksided Trønder and Nordland Cattle (STN). The NRF breed is by far the most common dairy breed in Norway, since approximately $97 \%$ of all dairy cattle belong to this breed. The STN breed has the biggest population size of the six old native cattle breeds still found in Norway; although it only has $0.17 \%$ of the population size of NRF. Average milk yields of STN cows are $65.6 \%$ of the yield average of NRF cows.

The NRF breed has been efficiently selected for higher milk production through a modern breeding programme since the breed's establishment in 1939. Since the 1970s the breeding goal has broadened and now includes milk production, growth, health and fertility traits. Due to its small population size, STN has had a more extensive breeding programme with a focus on breed type, increased milk production and avoidance of inbreeding.

When selecting herds for this study, many demands were to be fulfilled; the farms should have well established herds, in which the animals were familiar with each other and the grazing areas, should practise summer farming on semi-natural 
Table I. Milk production and herd size in 2002 for the two studied farms, and the corresponding national means.

\begin{tabular}{|c|c|c|c|c|c|c|c|}
\hline & \multicolumn{3}{|c|}{ National figures } & \multicolumn{2}{|c|}{ Valdres } & \multicolumn{2}{|c|}{ Skåbu } \\
\hline & $\begin{array}{l}\text { Total dairy } \\
\text { population }\end{array}$ & STN & NRF & STN & NRF & STN & NRF \\
\hline Population size & 286000 & 475 & 277000 & 5 & 4 & 6 & 3 \\
\hline $\mathrm{kg}$ milk per cow & 6190 & 4060 & 6190 & 4444 & 5628 & 4538 & 6036 \\
\hline Fat $\%$ & 4.2 & 4.2 & 4.2 & 4.4 & 4.2 & 3.9 & 3.9 \\
\hline Protein \% & 3.2 & 3.3 & 3.2 & 3.4 & 3.3 & 3.4 & 3.1 \\
\hline
\end{tabular}

References: Statistics Norway [39] and TINE [42].

STN: Blacksided Trønder and Nordland Cattle.

NRF: Norwegian Red Cattle.

grasslands, should have both NRF and STN cows and there should be at least 10 cows in each herd. Furthermore, it was of interest to have cows of about the same relative similar age and lactation stage.

Two farms practising traditional summer farming based on semi-natural grasslands in mountain areas were chosen for the study. The two summer farms were Skogstadstølen in Valdres and Brenden in Skåbu, both situated in the county of Oppland in central Norway. The herds consisted of both purebred STN and purebred NRF cows, approximately $50 \%$ of each breed, and some crossbreds. However, only the purebred cows were included in the study.

Table I shows milk production and herd size in 2002 for the two studied farms, and the corresponding national averages. The milk production levels in the studied herds are below the national average for NRF and above the national average for STN. The herds are furthermore smaller than the national average herd size for dairy cattle, which in 2002 was 15.2 cows.

The herds have been grazing the mountain pastures every summer for more than fifty years, and hardly any new cows have been introduced to the herds, except for self recruitment. These conditions should secure no confounding with background experience in the study.
According to traditional summer farming practise, the cows were kept indoors in a small stanchion barn from the afternoon milking at around 18:00 $\mathrm{h}$, and turned out to the grasslands again after the milking the next morning at around 08:00 h. The cows were fed concentrates according to their milk yield [18], but no roughage was provided in the stanchion barn.

The cows' mean age was 5.8 years in Valdres and 4.4 years in Skåbu, with a span of 3-11 years. The average length of time since last calving was 7.6 months in Valdres and 5.5 months in Skåbu, with a span of 2-11 months. These conditions indicate that no confounding between age of cow, lactation month and breed should be expected.

\subsection{Study sites}

Information about the climate and location of the two study sites is given in Table II. Climate data are based on data from local weather stations. The climate at both study sites is bio-climatically characterised as the transitional section (OC) between the weak oceanic $(\mathrm{O} 1)$ and the weak continental (C1) section [27]. This section is characterised by an annual precipitation of $500-800 \mathrm{~mm}$; frost in late spring and in early autumn, and low winter temperatures. This often results in deeply frozen 
Table II. Geographical and climatic information about the study sites.

\begin{tabular}{|c|c|c|}
\hline & Valdres & Skåbu \\
\hline Name of summer farm & Skogstadst $\varnothing$ len & Brenden \\
\hline Municipiality & Vestre Slidre & Sør Fron \\
\hline Meters above sea level & 1000 & 935 \\
\hline $\begin{array}{l}\text { Vegetation zone } \\
\text { (Moen 1999) }\end{array}$ & $\begin{array}{l}\text { Unforested area } \\
\text { in the northern } \\
\text { boreal veg. zone }\end{array}$ & $\begin{array}{l}\text { Forested area in the } \\
\text { northern boreal } \\
\text { veg. zone }\end{array}$ \\
\hline $\begin{array}{l}\text { Climatic zone } \\
\text { (Moen 1999) }\end{array}$ & \multicolumn{2}{|c|}{ Transitional section $(\mathrm{OC})$} \\
\hline Yearly precipitation & $570 \mathrm{~mm}$ & $600 \mathrm{~mm}$ \\
\hline Yearly mean temperature & $-1.7^{\circ} \mathrm{C}$ & $0.5^{\circ} \mathrm{C}$ \\
\hline $\begin{array}{l}\text { Mean temperature in July } \\
\text { (Warmest month in the year) }\end{array}$ & $10.2^{\circ} \mathrm{C}$ & $11.0^{\circ} \mathrm{C}$ \\
\hline
\end{tabular}

References [2,14,22,27].

ground due to thin snow cover. Oceanic plant species are rare, continental species and vegetation types occur [12].

Skåbu is situated in an area with many types of bedrock. The dominating baserich bedrocks are phyllite, gabbro and leuconorite with a high weathering capacity, giving rise to nutrient-rich soils. Additionally, there are small patches of acid bedrocks such as granite and anortosite, with a lower weathering capacity. Such bedrocks give rise to less fertile soils [38]. In the study area in Valdres, the bedrock consists entirely of a less basic phyllite type [26], and the soils are thus poorer than the base rich soils in Skåbu.

Transhumance (summer dairy farming) has been conducted in both areas for centuries. Numerous livestock herds used to graze these grasslands every summer. However, the total number of dairy herds in Norway has decreased to $2 / 3$ since 1950 , with a resulting decline in summer dairy farming. The studied areas today have a very low grazing pressure. The summer farm Brenden in Skåbu is now the only summer farm in this area practising transhumance, and the area is growing over. In Valdres, summer dairy farming is still more common. There are three other grazing herds of cattle and sheep in the surrounding areas of the summer farm Skogstadstølen With vast grazing areas available, the grazing pressure must still be characterised as low.

The grazing period at both study sites is usually from late June/early July to late August/early September, depending on the weather.

\subsection{Grazing value of the recorded vegetation types and plants}

Due to the large variation in vegetation types and plant species growing in the semi-natural mountain grasslands and the short and intense growing season with rapid changes in plant composition and growth stage, general nutrient analyses of this kind of vegetation are work intensive and thus scarce. However, in the 1920s Bjor and Graffer [5], ResvollHolmsen [33] and Vigerust [43] performed studies on the grazing value of plant species from semi-natural mountain grasslands. In Table III, plant species recorded by Bjor and Graffer [5], Rekdal [32], Resvoll-Holmsen [33] and Vigerust [43] to be of high grazing value are marked with bold print. Bjor and Graffer [5] reported that cattle graze and prefer grass 
Table III. Recorded grazed vegetation types at the two study sites and plant species recorded in these vegetation types. The vegetation types in the table are classified after the system of Fremstad [12], and the ones recorded in the table are the following: A4c = Bilbery woodland, bilberrycrowberry st.; Vaccinium myrtillus - Empetrum nigrum coll. woodland. C2a $=$ Tall-herb - downy birch st.; Tall-herb Betula pubescens spp. pubescens st. woodland. C2c $=$ Low-herb st. scattered with tall herb woodland. G3 = Tufted hair-grass grassland; Deschampsia cespitosa grassland. G4 = Common bent - red fescue - sweet vernal-grassland; Agrostis capillaris - Festuca rubra - Anthoxanthum odoratum grassland. G4c = Alpine cat's-tail - meadow-grass st.; Phleum alpinum Poa pratensis ssp. alpigena st. grassland. G5b = Mat-grass - alpine lady's-mantle; Nardus stricta - Alchemilla alpina st. grassland. G8 = Intermediate/dry medium base-rich lowland grassland. Lawn $=$ Cultivated areas around new cottages in the area. The notations $\mathrm{X}, \mathrm{C}$ and $\mathrm{D}$ code for the observed amount of the species within the recorded vegetation type, where $\mathrm{X}=$ more scarcely found, $\mathrm{C}=$ common, $\mathrm{D}=$ dominating. The species in bold print are recorded to be important grazing species in semi-natural mountain pastures $[5,32,33,43]$.

\begin{tabular}{|c|c|c|c|c|c|c|c|}
\hline \multirow[b]{2}{*}{ Recorded species } & \multicolumn{4}{|c|}{$\begin{array}{l}\text { Grazed vegetation } \\
\text { types in Skåbu }\end{array}$} & \multicolumn{3}{|c|}{$\begin{array}{l}\text { Grazed vegetation } \\
\text { types inValdres }\end{array}$} \\
\hline & $\mathrm{A} 4 \mathrm{c}$ & $\mathrm{C} 2 \mathrm{a} / \mathrm{C} 2 \mathrm{c}$ & G4/G8 & Lawn & $\mathrm{A} 4 \mathrm{c}$ & G3 & G4c/G5b \\
\hline Bushes, heather and trees & & & & & & & \\
\hline Betula nana ssp. nana & $\mathrm{X}$ & & & & $\mathrm{X}$ & & $\mathrm{X}$ \\
\hline Juniperus communis ssp. communis & $\mathrm{X}$ & $\mathrm{C}$ & $\mathrm{X}$ & & $\mathrm{C}$ & & $\mathrm{X}$ \\
\hline Rubus idaeus & & $\mathrm{X}$ & & & & & \\
\hline Rubus saxatilis & & $\mathrm{X}$ & & & & & \\
\hline Salix caprea ssp. caprea & & $\mathrm{X}$ & & & & & \\
\hline Salix herbacea & & & & & & & $\mathrm{X}$ \\
\hline Salix spp. & $\mathrm{X}$ & $\mathrm{X}$ & $\mathrm{X}$ & & & $\mathrm{X}$ & $\mathrm{X}$ \\
\hline Arctostaphylos uva-ursi & & $\mathrm{X}$ & & & & & \\
\hline Calluna vulgaris & & & $X$ & & & & $\mathrm{X}$ \\
\hline Empetrum nigrum coll. & $\mathrm{X}$ & $\mathrm{X}$ & & & $\mathrm{D}$ & & $\mathrm{X}$ \\
\hline Vaccinium myrtillus & $\mathrm{D}$ & $\mathrm{X}$ & $\mathrm{X}$ & & $\mathrm{D}$ & & $\mathrm{X}$ \\
\hline Vaccinium uliginosum ssp. uliginosum & $\mathrm{X}$ & $\mathrm{X}$ & $\mathrm{X}$ & & $\mathrm{X}$ & & $\mathrm{X}$ \\
\hline Vaccinium vitis-idaea & $\mathrm{X}$ & $\mathrm{X}$ & $\mathrm{X}$ & & $\mathrm{D}$ & & $\mathrm{X}$ \\
\hline Betula pubescens coll. & $\mathrm{D}$ & $\mathrm{C}$ & $\mathrm{X}$ & & & & \\
\hline Betula pubescens ssp. czerepanovii & & & & & $\mathrm{D}$ & & \\
\hline Picea abies ssp. abies & $\mathrm{X}$ & $\mathrm{X}$ & & & $\mathrm{X}$ & & \\
\hline Pinus sylvestris var. sylvestris & $\mathrm{X}$ & $\mathrm{X}$ & & & & & \\
\hline Sorbus aucuparia ssp. aucuparia & & & & & $\mathrm{X}$ & & \\
\hline Graminides & & & & & & & \\
\hline Agrostis capillaris & $X$ & $X$ & $X$ & $\mathrm{C}$ & & & $\mathrm{X}$ \\
\hline Alopecurus geniculatus & & & & & & & $\mathrm{X}$ \\
\hline Anthoxanthum odoratum coll. & $\mathrm{X}$ & $\mathrm{X}$ & $\mathrm{X}$ & & $\mathrm{X}$ & & $\mathrm{C}$ \\
\hline Avenella flexuosa & $\mathrm{D}$ & $\mathrm{C}$ & $\mathrm{X}$ & $\mathrm{C}$ & $\mathrm{D}$ & & $\mathrm{X}$ \\
\hline Avenula pubescens & & $\mathrm{X}$ & $\mathrm{X}$ & & & & \\
\hline Deschampsia cespitosa ssp. cespitosa & $\mathrm{X}$ & $\mathrm{C}$ & $\mathrm{C}$ & & & $\mathrm{D}$ & $\mathrm{C}$ \\
\hline Festuca ovina ssp. ovina & $\mathrm{X}$ & & $\mathrm{X}$ & & $\mathrm{X}$ & & $\mathrm{X}$ \\
\hline Festuca rubra ssp.rubra & $\mathrm{X}$ & & $\mathrm{X}$ & $\mathrm{C}$ & & & $\mathrm{X}$ \\
\hline Melica nutans & $\mathrm{X}$ & $\mathrm{X}$ & & & & & \\
\hline Nardus stricta & & $\mathrm{X}$ & $\mathrm{X}$ & & $\mathrm{X}$ & & $\mathrm{C}(\mathrm{G} 4 \mathrm{c}) \mathrm{D}(\mathrm{G} 5 \mathrm{~b})$ \\
\hline Phleum alpinum & & $\mathrm{X}$ & $\mathrm{C}$ & & & $\mathrm{X}$ & $\mathrm{C}$ \\
\hline Phleum pratense ssp. pratense & & $\mathrm{X}$ & & & & & \\
\hline Poa alpina var. alpina & & & $\mathrm{X}$ & & & & $\mathrm{C}$ \\
\hline Poa spp. & $X$ & & & & $\mathrm{X}$ & $\mathrm{X}$ & $\mathrm{X}$ \\
\hline Carex bigelowii ssp. bigelowii & & $\mathrm{X}$ & & & & & $\mathrm{X}$ \\
\hline Carex brunnescens ssp. brunnescens. & & & $\mathrm{X}$ & & & & $\mathrm{X}$ \\
\hline
\end{tabular}


Table III. Continued.

\begin{tabular}{|c|c|c|c|c|c|c|c|}
\hline \multirow[b]{2}{*}{ Recorded species } & \multicolumn{4}{|c|}{$\begin{array}{c}\text { Grazed vegetation } \\
\text { types in Skåbu }\end{array}$} & \multicolumn{3}{|c|}{$\begin{array}{c}\text { Grazed vegetation } \\
\text { types inValdres }\end{array}$} \\
\hline & $\mathrm{A} 4 \mathrm{c}$ & $\mathrm{C} 2 \mathrm{a} / \mathrm{C} 2 \mathrm{c}$ & G4/G8 & Lawn & $\mathrm{A} 4 \mathrm{c}$ & G3 & $\mathrm{G} 4 \mathrm{c} / \mathrm{G} 5 \mathrm{~b}$ \\
\hline Carex capillaris ssp. capillaris & & & $\mathrm{X}$ & & & & \\
\hline Carex nigra var. nigra & & $\mathrm{X}$ & $\mathrm{X}$ & & & & $X$ \\
\hline Carex pallescens & & & $\mathrm{X}$ & & $X$ & & $\mathrm{X}$ \\
\hline Carex panicea & & & & & & & $X$ \\
\hline Carex vaginata & & & & & & & $\mathrm{X}$ \\
\hline Eriophorum vaginatum & & & & & & & $\mathrm{X}$ \\
\hline Juncus filiformis & & & $\mathrm{X}$ & & & & $\mathrm{X}$ \\
\hline Luzula multiflora ssp. frigida & $\mathrm{X}$ & & $\mathrm{X}$ & & $\mathrm{X}$ & $\mathrm{X}$ & $\mathrm{C}$ \\
\hline Luzula pilosa & $\mathrm{X}$ & $\mathrm{X}$ & $\mathrm{X}$ & & $\mathrm{X}$ & & \\
\hline Luzula spicata & & & & & & & $\mathrm{X}$ \\
\hline Herbs & & & & & & & \\
\hline Achillea millefolium ssp. millefolium & & $\mathrm{X}$ & $\mathrm{X}$ & & $X$ & $\mathrm{X}$ & $\mathrm{X}$ \\
\hline Aconitum lycoctonum ssp. septentrionale & & $\mathrm{C}$ & & & & $\mathrm{X}$ & $\mathrm{X}$ \\
\hline Alchemilla alpina & & & $X$ & & $\mathrm{X}$ & $\mathrm{C}$ & $\mathrm{D}$ \\
\hline Alchemilla spp. & & $\mathrm{X}$ & $X$ & & & $X$ & $X$ \\
\hline Angelica sylvestris & & $\mathrm{X}$ & & & & & \\
\hline Antennaria alpina ssp. alpina/A. dioica. & $X$ & $\mathrm{X}$ & $\mathrm{X}$ & & $X$ & & $\mathrm{X}$ \\
\hline Astragalus alpinus coll. & & $\mathrm{X}$ & $\mathrm{X}$ & & & & \\
\hline Bartsia alpine & & $\mathrm{X}$ & $\mathrm{X}$ & & & & \\
\hline Bistorta vivipara & $X$ & $X$ & $\mathrm{X}$ & & $\mathrm{X}$ & $\mathrm{X}$ & $\mathrm{C}$ \\
\hline Botrychium lunaria & & & $\mathrm{X}$ & & & & \\
\hline Campanula rotundifolia ssp. rotundifolia & & $\mathrm{C}$ & $\mathrm{X}$ & & & $X$ & $\mathrm{X}$ \\
\hline Cerastium cerastoides & & & & & & & $\mathrm{X}$ \\
\hline Cerastium fontanum ssp. vulgare & & & $\mathrm{X}$ & & & & $\mathrm{X}$ \\
\hline Cicerbita alpina & & $\mathrm{X}$ & & & & & \\
\hline Cirsium heterophyllum & & $\mathrm{X}$ & & & & & \\
\hline Coeloglossum viride & & & $\mathrm{X}$ & & & & \\
\hline Dactylorhiza fuchsii & & & $\mathrm{X}$ & & & & \\
\hline Equisetum hyemale & & $\mathrm{X}$ & & & & & \\
\hline Equisetum sylvaticum & $\mathrm{X}$ & $\mathrm{X}$ & & & & & \\
\hline Erigeron borealis & & & $\mathrm{X}$ & & & & \\
\hline Euphrasia wettsteinii & & $\mathrm{X}$ & $\mathrm{X}$ & & & & $\mathrm{X}$ \\
\hline Euphrasia stricta coll. & & & $\mathrm{X}$ & & & & \\
\hline Filipendula ulmaria & & $\mathrm{X}$ & $\mathrm{X}$ & & & & \\
\hline Galium boreale & & & $\mathrm{X}$ & & & & \\
\hline Gentiana nivalis & & & $\mathrm{X}$ & & & & \\
\hline Gentianella campestris ssp. campestris & & $\mathrm{X}$ & $\mathrm{X}$ & & & & \\
\hline Geranium sylvaticum & $\mathrm{X}$ & $\mathrm{C}$ & $\mathrm{X}$ & & $\mathrm{X}$ & $\mathrm{X}$ & \\
\hline Geum rivale & $\mathrm{X}$ & $\mathrm{X}$ & & & & & \\
\hline Gymnocarpium dryopteris & & & & & $\mathrm{C}$ & & \\
\hline Hieracium lactucella & & & $\mathrm{X}$ & & & & \\
\hline Hieracium vulgatum coll. & & & & & $\mathrm{X}$ & & \\
\hline Knautia arvensis & & & $\mathrm{X}$ & & & & \\
\hline Leontodon autumnalis & $X$ & $X$ & $\mathrm{C}$ & & & $X$ & $\mathrm{C}$ \\
\hline Lycopodium annotinum ssp. annotinum & & & & & $\mathrm{X}$ & & \\
\hline Maianthemum bifolium & & & & & $X$ & & \\
\hline Melampyrum pratense & $\mathrm{X}$ & $\mathrm{X}$ & & & $\mathrm{X}$ & & \\
\hline Melampyrum sylvaticum & & & & & $\mathrm{X}$ & & \\
\hline Moneses uniflora & & $\mathrm{X}$ & & & $\mathrm{X}$ & & \\
\hline Myosotis spp. & & $\mathrm{X}$ & & & & & \\
\hline Omalotheca norvegica & & & & & & $X$ & \\
\hline Oxalis acetosella & & $\mathrm{X}$ & & & & & \\
\hline
\end{tabular}


Table III. Continued.

\begin{tabular}{|c|c|c|c|c|c|c|c|}
\hline \multirow[b]{2}{*}{ Recorded species } & \multicolumn{4}{|c|}{$\begin{array}{l}\text { Grazed vegetation } \\
\text { types in Skåbu }\end{array}$} & \multicolumn{3}{|c|}{$\begin{array}{l}\text { Grazed vegetation } \\
\text { types inValdres }\end{array}$} \\
\hline & $\mathrm{A} 4 \mathrm{c}$ & $\mathrm{C} 2 \mathrm{a} / \mathrm{C} 2 \mathrm{c}$ & G4/G8 & Lawn & $\mathrm{A} 4 \mathrm{c}$ & G3 & G4c/G5b \\
\hline Parnassia palustris & $\mathrm{X}$ & & $\mathrm{X}$ & & & & \\
\hline Pedicularis lapponica & & $\mathrm{X}$ & & & & & \\
\hline Plantago media & & & $\mathrm{X}$ & & & & \\
\hline Potentilla crantzii & & & $\mathrm{X}$ & & & & $\mathrm{X}$ \\
\hline Potentilla erecta & & & $\mathrm{X}$ & & $\mathrm{X}$ & & $\mathrm{X}$ \\
\hline Primula scandinavica & & & $\mathrm{X}$ & & & & \\
\hline Prunella vulgaris & & & & & & & $\mathrm{X}$ \\
\hline Pulsatilla vernalis & & & $\mathrm{X}$ & & & & \\
\hline Pyrola minor & & $\mathrm{X}$ & $\mathrm{X}$ & & & & \\
\hline Pyrola norvegica & & $\mathrm{X}$ & $\mathrm{X}$ & & & & \\
\hline Ranunculus acris coll. & $\mathrm{X}$ & $\mathrm{X}$ & $\mathrm{X}$ & & $\mathrm{X}$ & $\mathrm{X}$ & $\mathrm{X}$ \\
\hline Rhinanthus minor coll. & & $\mathrm{X}$ & $\mathrm{X}$ & & & & \\
\hline Rumex acetosa ssp. acetosa & $X$ & $\mathrm{X}$ & $\mathrm{X}$ & & $\mathrm{X}$ & $\mathrm{X}$ & $\mathrm{X}$ \\
\hline Sagina saginoides & & & & & & & $\mathrm{X}$ \\
\hline Saussurea alpina & & $\mathrm{X}$ & $\mathrm{X}$ & & & & \\
\hline Selaginella selaginoides & & & $\mathrm{X}$ & & & & \\
\hline Sibbaldia procumbens & & & $\mathrm{X}$ & & & & $\mathrm{X}$ \\
\hline Silene dioica & & $\mathrm{X}$ & & & & & \\
\hline Silene vulgaris & $\mathrm{X}$ & & $\mathrm{X}$ & & & & \\
\hline Solidago virgaurea coll. & $\mathrm{X}$ & $\mathrm{X}$ & $\mathrm{X}$ & & $\mathrm{X}$ & & \\
\hline Taraxacum spp. & & $\mathrm{X}$ & $\mathrm{X}$ & & & & $\mathrm{X}$ \\
\hline Thalictrum alpinum & & $\mathrm{X}$ & $\mathrm{X}$ & & & & \\
\hline Trientalis europaea & $\mathrm{X}$ & $\mathrm{X}$ & & & $\mathrm{C}$ & & $\mathrm{X}$ \\
\hline Trifolium hybridum ssp. hybridum & & & & $\mathrm{C}$ & & & \\
\hline Trifolium medium & & & $\mathrm{X}$ & & & & \\
\hline Trifolium pratense & & & $\mathrm{X}$ & $\mathrm{C}$ & & & \\
\hline Trifolium repens & & $\mathrm{C}$ & $\mathrm{C}$ & & & $\mathrm{X}$ & $\mathrm{C}$ \\
\hline Trollius europaeus & & $\mathrm{X}$ & & & & & \\
\hline Urtica dioica ssp. dioica & & $\mathrm{X}$ & $\mathrm{X}$ & & & $\mathrm{X}$ & $\mathrm{X}$ \\
\hline Valeriana sambucifolia ssp. sambucifolia & & $\mathrm{X}$ & & & & & \\
\hline Veronica alpina ssp. alpina & & & & & & & $\mathrm{X}$ \\
\hline Veronica officinalis & & & $\mathrm{X}$ & & & & $X$ \\
\hline Veronica serpyllifolia ssp. serpyllifolia & & & & & & $\mathrm{X}$ & $\mathrm{X}$ \\
\hline Vicia cracca & & & $\mathrm{X}$ & & & & $\mathrm{X}$ \\
\hline Viola biflora & & $\mathrm{X}$ & $\mathrm{X}$ & & & $\mathrm{X}$ & $\mathrm{X}$ \\
\hline Viola canina coll. & & & & & $\mathrm{X}$ & & \\
\hline Viola riviniana & & $\mathrm{X}$ & & & & & \\
\hline Viola sp. & & & $\mathrm{X}$ & & & & \\
\hline
\end{tabular}


in general, and especially species such as Agrostis capillaris, Anthoxanthum odoratum coll., Deschampsia cespitosa ssp. cespitosa, Avenella flexuosa and Festuca ovina ssp. ovina. In addition to grass, sedges (Carex spp.) and herbs are recorded to be preferred grazing plants. Studies by Garmo $[16,17]$ state that sedges (Carex spp.) collected in July and August on mountain grasslands in Norway, have a higher content of crude protein and less crude fibre than grass species during the entire grazing season. The results from Garmo $[16,17]$ thus indicate that sedges in general have a higher nutrient value than grass.

One plant species to be mentioned in addition to the preferred grazing species is Nardus stricta. Nardus stricta is not regarded as a valuable or preferred grazing species, due to low digestibility and stiff straw-like leaves. Still, Nardus stricta is known to be grazed to a certain extent, maybe due to the easy accessibility in the grasslands dominated by the species [35].

\subsection{Recording procedures}

Two technicians followed each herd during the daily grazing period and collected faeces samples, took notes about the grazing areas' botanical composition, made brief descriptions of the recorded vegetation, and marked out if the herds stopped for grazing or just walked through the different vegetation types. Also the technicians recorded various activities of the cows every ten minutes. The results of these recordings are presented by Sæther et al. [41]. The recording period was in week 28 (July) and 32 (August) in Valdres and week 29 (July) and 33 (August) in Skåbu. The herds were observed from 08:00 $\mathrm{h}$, after the morning milking, to approximately $16: 00 \mathrm{~h}$ when the herds returned without escort to the stanchion barn for the evening milking at 18:00 h. On av- erage, the herds were observed 9.1 hours in Valdres and 8.8 hours in Skåbu, with a span of 6.8-11.5 hours per day.

The vegetation descriptions and maps, see Figures 1 and 2, are based on four-days of fieldwork by this study's botanist during the first recording week early in July, supplied with vegetation data recorded by the technicians. The botanist followed the herds during two days at each study site and recorded all observed plant species on the areas where the herds stopped for grazing. In addition, the regrowth situation, grazing pressure, if the areas had been fertilised, surrounding vegetation etc. were noted. Some areas pointed out by the cattle owners as preferred grazing areas were included, even if these areas were not grazed during the four-day fieldwork. The lists of observed plant species were then transformed into forms and used by the technicians for their daily recordings in the areas where the herds stopped for grazing. The nomenclature followed Lid and Lid [24]. Finally, all botanical data were converted into vegetation types according to the system of Fremstad [12]. In the further vegetation descriptions, codes in brackets refer to the system of Fremstad [12], which is one of two prevailing systems for vegetation mapping in Norway. It is also the most differentiated regarding semi-natural grasslands. The amount of recorded plant species within each vegetation type was classified into three levels, "only scarcely found", "common" or "dominating", a classification recommended by Elven (personal communication) when making more sketch alike vegetation descriptions.

The global positioning system (GPS) unit, a Magellan GPS 315, was used to track the grazing cattle. Magellan GPS 315 has a position accuracy of $+/-7$ metres. The bell cow (an efficient leader) in each herd wore a GPS receiver during the recording period, collecting data about the daily walking route chosen by the respective herd. The receiver was mounted to the 


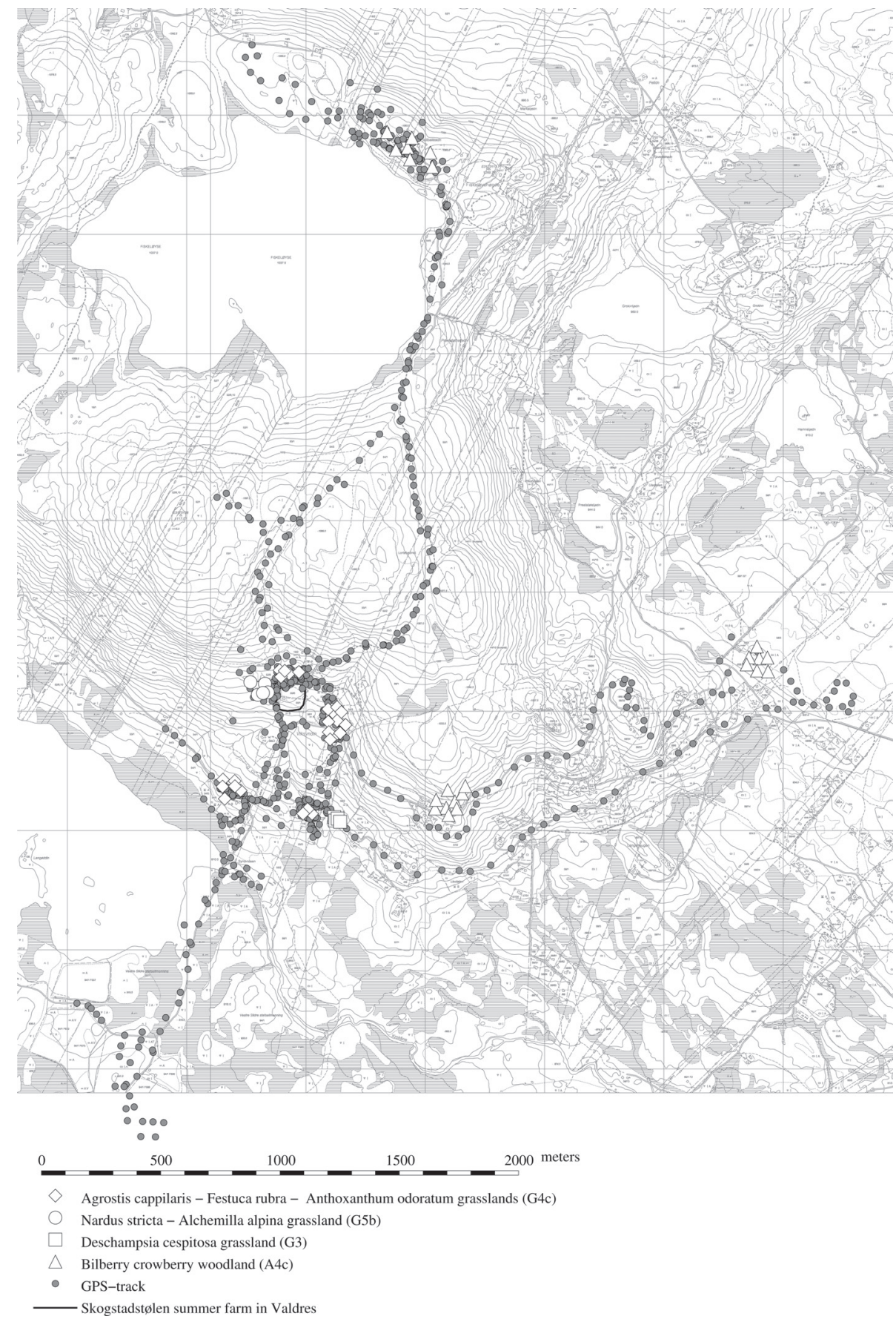

Figure 1. Map over Skogstadstølen summer farm in Valdres, showing the GPS tracks and some of the localisations of the described vegetation types. 

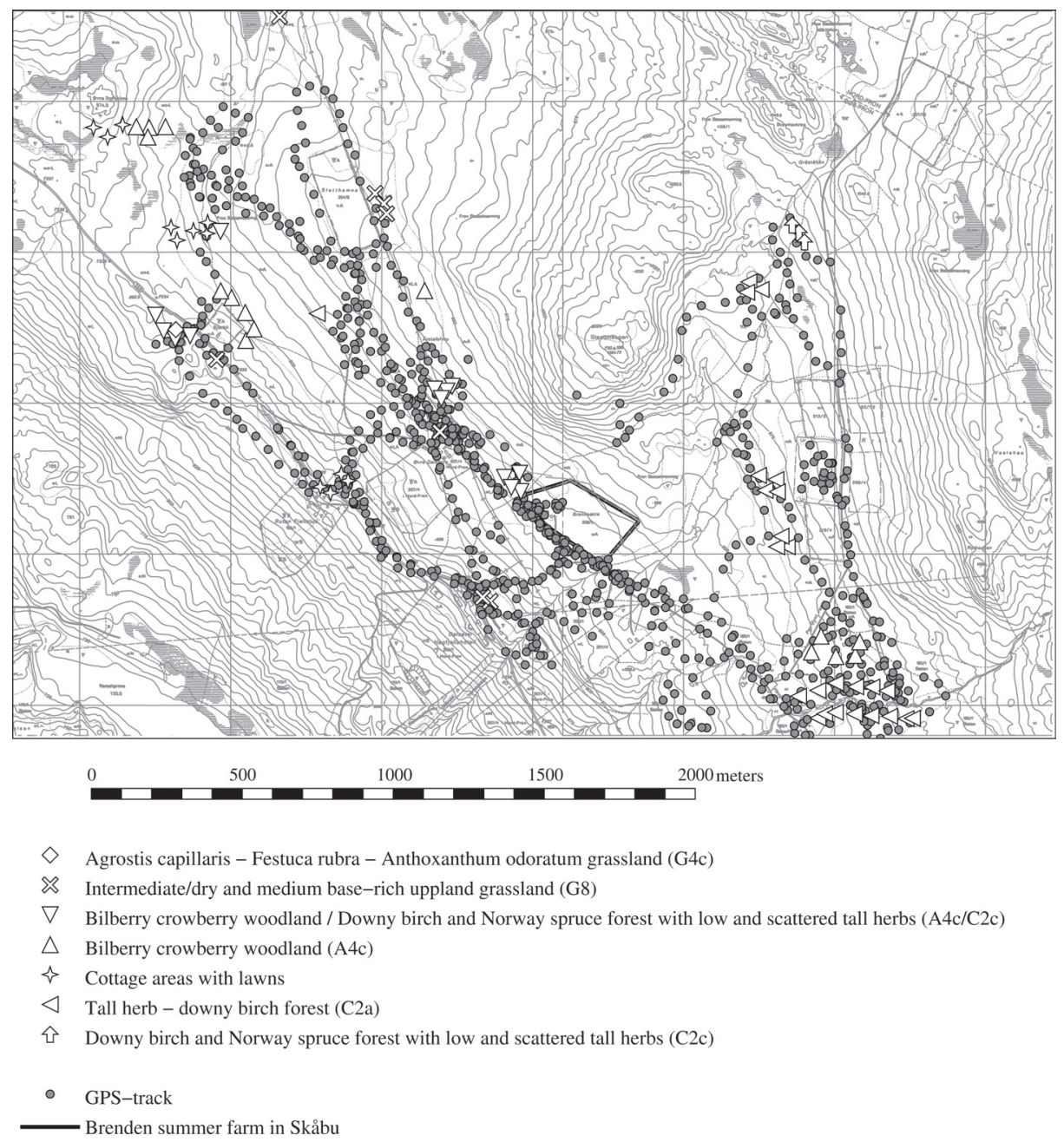

Figure 2. Map over Brenden summer farm in Skåbu, showing the GPS tracks and some of the localisation of the described vegetation types.

collar of the bell cow while she was still in the box during milking time in the morning and taken off in the box after she had returned in the afternoon. As the cow moved, the unit logged the geographical position. The data points were collected when the cow had moved a certain distance, and do thus not indicate the length of time spent by the herd on a given area, but merely provide a record of their movement pattern. The data collected was transferred to a PC at the end of each day. The data from all days were later integrated in the GIS (Geographical Information System), making it possible to analyse and present the movements of the cows on a map.

\subsection{Microhistological analyses}

Faeces samples were collected during the daily grazing periods, picked up just 
after the cows had deposited them. They were labelled with the cow's ID and date and hour of collection. When still warm they were put in a cooling bag, and every evening the day's samples were put in a freezer $\left(-18{ }^{\circ} \mathrm{C}\right)$, where they were stored until analysis. In Skåbu, 14 faeces samples from each breed were collected, and in Valdres, 10 faeces samples from STN and 11 faeces samples from NRF were collected. In total, 49 faeces samples from 20 different cows were collected.

The faeces samples were prepared for microhistological analyses, following the procedures of Garcia-Gonzalez [15]. After thawing, about 1 tablespoon was lightly ground in a mortar. About $1 \mathrm{~mL}$ of each sample was placed in a test tube with $4 \mathrm{~mL}$ concentrated nitric acid. The tube was placed in a boiling water bath for 1 minute. Then the sample was diluted with $200 \mathrm{~mL}$ water and boiled for another 4 minutes. The suspension was passed through 1.00 and $0.20 \mathrm{~mm}$ sieves and rinsed with water. The $0.20 \mathrm{~mm}$ fraction was conserved in a mixture of $85 \%$ ethanol $(70 \%) ; 10 \%$ formalin (40\%) and 5\% glacial acetic acid. The fragments were dispersed on microscope slides in a $50 \%$ aqueous solution of glycerine. Cover-slips $(20 \times 40 \mathrm{~mm})$ were then fixed to the slides and sealed with nail varnish. Two slides from each sample were prepared and analysed, labelled as an "a" and " $b$ " test, and the means from these two tests were used in further statistical treatment of the data.

All fragments intersecting a $1 \mathrm{~mm}$ wide line along $40 \mathrm{~mm}$ long transects were examined. The transects were placed $3 \mathrm{~mm}$ apart. A minimum of 200 plant fragments was identified on each slide.

The concern of varying digestibility of the plants is a topic of debate, and there is literature both to support and refute its impact on microhistology. This debate is found to be of minor importance in this study, since the main task is to identify possible differences in plant and vegetation preferences between two breeds when grazing in the same vegetation, and there is no reason to believe that the digestibility of the plants is different in the two breeds. The results from the microhistological analyses were used in this study to compare the two breeds on the basis of remaining and identified fragments and vegetation maps.

\subsection{Plant species, plant genera and plant groups used in statistical analysis}

The 49 faeces samples were analysed for fragments from 25 plant species and plant genera, total fragments and total fibres. In addition to these 25 plant species and plant genera, four plant groups were constructed, these are the following:

(1) Total grass = Deschampsia cespitosa, Avenella flexuosa, Festuca rubra ssp. rubra, Festuca ovina ssp. ovina, Festuca spp., Poa spp., Molinia caerulea, Agrostis spp., Anthoxanthum odoratum coll., Phleum alpinum, Nardus stricta, Melica nutans, Alopecurus geniculatus, unidentified grass species.

(2) Total fescue = Festuca rubra ssp. rubra, Festuca ssp. ovina, Festuca spp.

(3) Total bushes = Salix spp., Juniperus communis.

(4) Total heather $=$ Vaccinium myrtillus, Calluna vulgaris.

\subsection{Statistical model}

In the statistical analysis the possible effects of breed (STN and NRF), farm (Skåbu and Valdres) and month (July and August) were included as fixed effects together with the interaction breed $*$ farm. The effect of cow within breed was included as a random effect to adjust for variation between individuals within breed.

The PROC MIXED procedure in the SAS program (SAS system for windows, 
V8) was used for the statistical analysis, according to the following model:

$$
\begin{gathered}
y_{i j k l}=\mu+\text { breed }_{i}+\text { farm }_{j}+\text { month }_{k}+ \\
\text { farm }^{*} \text { breed }_{i j}+\text { cow }_{l}\left(\text { breed }_{i}\right)+e_{i j k l m}
\end{gathered}
$$

where $y$ denotes the percentage of each plant species, plant genera or plant group from the total of observed fragments in the faeces samples.

$\mu=$ verall mean.

breed $_{i}=$ fixed effect of breed $i(i=1,2)$. farm $_{j}=$ fixed effect of farm $(j=1,2)$. 1,2).

$$
\text { month }_{k}=\text { fixed effect of month }(j=
$$

farm $^{*}$ breed $_{i j}=$ interaction of farm $_{j}$ and breed $_{i}$.

cow $_{l}\left(\right.$ breed $\left._{i}\right)=$ random effect of $\operatorname{cow}_{l}$ within breed $_{i}$.

$e_{i j k l}$ is the effect of error term of the fixed effects $\operatorname{breed}_{i}$, farm $_{j}$, month $_{k}$, the interaction between farm fand $_{j}$ breed ${ }_{i}$, and the random effect of $\operatorname{cow}_{l}$ within breed $_{i}$.

\section{RESULTS}

\subsection{Vegetation descriptions}

The recorded plant species and grazed vegetation types in Valdres and Skåbu are listed in Table III. The species in bold print are recorded to be important grazing species in semi-natural mountain pastures $[5,32,33,43]$.

Both study sites have species rich grasslands. The vegetation in Valdres is, however, mainly characterised by common grassland species, while the vegetation in Skåbu is characterised by many base demanding species. In total, 123 species were found at the two sites. Amongst these, 51 species were only found in Skåbu and 20 were only found in Valdres (Tab. III).

The recorded occurrence of some of the plant species within the same vegetation type varies between Skåbu and Valdres, see Table III. Juniperus communis ssp. communis, Empetrum nigrum coll. and Vaccinium vitis-ideae are all recorded only as "more scarcely occurring" in the Bilberry woodland, bilberry-crowberry woodland $(\mathrm{A} 4 \mathrm{c})$ vegetation in Skåbu, whereas the same vegetation types in Valdres are recorded as "common" or "dominating" species. This variation within a vegetation type is explained by the fact that vegetation types according to Fremstad [12] are quite broadly defined, and therefore include variation regarding occurrence and frequencies of different plant species due to local conditions.

The GPS data from Valdres cover approximately $18 \mathrm{~km}^{2}$. This area contains many small patches of grassland close to summer farms or former summer farms, which are now often used as mountain cabins. Heaths often surround the grassland patches. The terrain is relatively hilly and undulating, resulting in varying ecological conditions within the grasslands. Due to lack of forests in the near surroundings of the summer farms, small elevations and knolls are more exposed to wind and drought, thus further enhancing the smallscale differences in the grazed areas.

The most common grassland vegetation type in Valdres is Agrostis cappilaris Festuca rubra - Anthoxanthum odoratum grasslands on intermediate nutrient rich bedrock (G4c) (Tab. III). This vegetation type is characterised by many common and small-sized grasses and herbs with low to medium demands of base rich soil. The distribution of the species within the grassland is not even. Nardus stricta and other drought-resistant species often grow on the top of small elevations, while species indicating better moisture conditions, e.g. certain Carex species, dominate on lower and more humid parts of the grasslands. Vaccinium myrtillus was also often found here. Another grassland type in the Valdres area is dominated by Nardus stricta as a result of too heavy grazing for many years. It is classified as Nardus stricta - Alchemilla alpina grasslands (G5b) and contains many of the same species as G4c. 
The grasslands in Valdres are often surrounded by Juniperus communis - Betula nana heath, poor subtype (S2a), a secondary vegetation type after deforestation of A4c in the north-boreal vegetation zone. S2a is not described any further since this vegetation was hardly grazed. The study area also contains Betula pubescens ssp. czerepanovii woodland of Vaccinium myrtillus - Empetrum nigrum coll. type (A4c) with large amounts of Avenella flexuosa in the field layer (Fremstad [12]).

The investigated area around Brenden in Skåbu covers approximately $8 \mathrm{~km}^{2}$. The terrain here is less hilly and undulating than in Valdres. Thus, moisture conditions in the grasslands are more uniform, which also gives a more uniform distribution of plant species. Forests, protecting small elevations and knolls against wind and drought, surround the grasslands.

The grasslands in Skåbu are semidry to dry and medium base-rich upland grasslands (G8). They are grass and herb rich with many base-demanding species in addition to common meadow species. Some base-demanding species recorded here are Astragalus alpinus coll., Gentiana nivalis and Primula scandinavica. Species that characterise Agrostis cappilaris - Festuca rubra - Anthoxanthum odoratum grassland (G4) such as Carex pallescens, Carex brunnescens ssp. brunnescens, Carex nigra var. nigra, Avenella flexuosa and Phleum alpinum, however, also occur in this grassland type in Skåbu. The "lawns" around the cabins contain Avenella flexuosa, Agrostis cappilaris and cultivated species of Festuca rubra and Trifolium hybridum. Woodlands with Betula pubescens coll. and Pinus sylvestris ssp. sylvestris, classified as nutritious-rich types of bilberry-crowberry woodlands with a low-herb field layer scattered with tall herbs $(\mathrm{A} 4 \mathrm{c} / \mathrm{C} 2 \mathrm{c})$ cover certain parts of the area. The field layer in the woodlands also contains many of the species found in the open pastures and meadows, and
Deschampsia cespitosa, Avenella flexuosa and Geranium sylvaticum occur frequently here. A bush layer of Juniperus communis and Betula nana sometimes occurs in dry/semi-dry parts (A4c) of the forests and various Salix species in moister/wet parts (C2c). Tall-herb - Betula pubescens ssp. pubescens forest (C2a) is found along small streams and other wet parts of the forest. Tall herbs occurring here are among others Aconitum lycoctonum ssp. septentrionale, Cicerbita alpina, Cirsium helenoides, Geranium sylvaticum and Trollius europaeus. The most common grass species are Deschampsia cespitosa and Avenella flexuosa.

\subsection{Daily walking patterns}

The GPS recorded an average daily walking distance for the herd of $7.3 \mathrm{~km}$ in Valdres and $8.0 \mathrm{~km}$ in Skåbu. The GPS tracks in Figure 1 and Figure 2 show the daily walking routes of the herds. Note that the cows mainly walked along roads and paths, hardly making any short cuts through the terrain.

In Valdres, the cattle had to walk through the Juniperus communis-Betula nana heaths to either get to the small patches of grasslands near the summer farm or to the Betula forests which were 2-3 km from the summer farm, see Figure 1 . The field observations show that the cows, as a rule, did not stop for grazing on their way to the grazing areas.

In Skåbu, the grasslands, cabin lawns and the rich forest types in the near surroundings of the summer farm are good grazing areas. However, instead of just freely roaming around in these rich grazing areas, the GPS data (see Fig. 2) show that the cattle mainly followed established tracks within a radius of $1-2 \mathrm{~km}$ from the summer farm, and the technicians recorded that they grazed along these walking routes. This is in contrast to the grazing 
Table IV. The figures for the plant species, plant genera and plant groups are given as percentage of total fragments. The figures for "total fragments" and "total fibres" are actual findings.

\begin{tabular}{|c|c|c|c|}
\hline $\begin{array}{l}\text { Plant species, } \\
\text { plant genera } \\
\text { or plant group }\end{array}$ & Mean & $\begin{array}{l}\text { Plant species } \\
\text { plant genera } \\
\text { or plant group }\end{array}$ & Mean (std dev) \\
\hline Birch, Betula spp & $0.99(1.38)$ & $\begin{array}{l}\text { Matgrass } \\
\text { Nardus stricta }\end{array}$ & $3.82(3.06)$ \\
\hline Hedge apple, Salix spp. & $0.41(0.72)$ & $\begin{array}{l}\text { Mountain melic } \\
\text { Melica nutans }\end{array}$ & $0.06(0.18)$ \\
\hline Blueberry, Vaccinium myrtillus & $2.03(1.26)$ & $\begin{array}{l}\text { Water foxtail } \\
\text { Alopecurus geniculatus }\end{array}$ & $0.09(0.23)$ \\
\hline Heather, Calluna vulgaris & $2.13(1.45)$ & $\begin{array}{l}\text { Unidentified grass } \\
\text { Graminae }\end{array}$ & $12.80(3.00)$ \\
\hline Juniper, Juniperus communis & $0.48(0.50)$ & $\begin{array}{l}\text { Sedge species } \\
\text { Carex spp. }\end{array}$ & $8.36(6.16)$ \\
\hline Tufted hair-grass, Deschampsia cespitosa & $25.54(9.39)$ & $\begin{array}{l}\text { Horsetail } \\
\text { Equisetum spp. }\end{array}$ & $0.26(0.33)$ \\
\hline Wavy hair-grass, Avenella flexuosa & $15.08(7.57)$ & $\begin{array}{l}\text { Club moss } \\
\text { Lycopodium spp. }\end{array}$ & $0.01(0.04)$ \\
\hline Red fescue, Festuca rubra & $3.24(2.19)$ & $\begin{array}{l}\text { Moss } \\
\text { Bryophyta }\end{array}$ & $0.75(0.62)$ \\
\hline Sheep's fescue, Festuca ovina & $0.54(1.59)$ & Herbs & $8.37(5.01)$ \\
\hline Unidentified fescue, Festuca spp. & $7.04(3.32)$ & $\begin{array}{l}\text { Lichen } \\
\text { Lichenes }\end{array}$ & $0.03(0.07)$ \\
\hline Meadow grass, Poa spp. & $3.46(2.05)$ & Total grass & $76.13(5.84)$ \\
\hline Moor grass, Molinia caerulea & $0.30(0.39)$ & Total fescue & $10.83(4.88)$ \\
\hline Bent-grass, Agrostis spp. & $2.55(1.77)$ & Total bushes & $0.88(0.95)$ \\
\hline Sweet vernal gras, Anthoxanthum odoratum & $0.08(0.24)$ & Total fragments & $229.60(17.27)$ \\
\hline Alpine timothy, Phleum alpinum & $1.53(0.88)$ & Total fiber & $314.91(57.28)$ \\
\hline
\end{tabular}

std dev: Standard deviation.

pattern in Valdres, where the cattle usually did not stop along their walking route. The herd's preference to follow roads and paths in Skåbu results in longer daily walking distances than in Valdres, despite the occurrence of very good grazing areas in the vicinity of the summer farm.

\subsection{Results from the microhistological analyses}

Table IV shows the mean values for all plant species, plant genera and plant groups observed in the faeces samples. The cows had most fragments from grass
(76\%), distributed among 13 recognised species and genera in addition to a group of unidentified grass species (Graminae). The two single species with the highest share of observed fragments are Avenella flexuosa (25\%) and Deschampsia cespitosa (15\%) which agrees well with the recorded easy access to these species in the area and these species' generally accepted high grazing value. Herbs and Carex spp. in general are valuable grazing plants and together they contribute to almost $16 \%$ of the observed fragments. Another $6 \%$ of the fragments come from the Heather group and the Bushes group. 
Plant species, plant genera and plant groups with less than $2 \%$ total mean values for observed fragments are neither further commented nor included in further statistical analysis. This was due to the fact that they contributed very little to the total amount of observed plant material and had minor effects on the analytical results, even if some of them are considered to be of great grazing value, i.e. Salix spp., Festuca ovina, Anthoxanthum odoratum and Phleum alpinum [5, 32, 33, 43].

Table V presents the results from the statistical model, showing that the effect of study site is significant for all the plant species, genera and groups tested in the model, whereas only month has a significant $(P<0.01)$ effect on Avenella flexuosa, Poa spp. and Agrostis spp., indicating that these plant species and genera are grazed differently in July and August. Fewer fragments of Avenella flexuosa and Agrostis spp. were observed in July (12.0\% and $1.9 \%$ respectively) than in August (18.0\% and $3.7 \%$ respectively). Poa spp. had an opposite trend, since the percentages of observed fragments in July were $4.1 \%$, compared to $2.4 \%$ in August.

The effect of breed was only significant for the plant species Nardus stricta, for which the STN breed had a higher share of fragments in the faeces samples than the NRF breed (Tab. V). The interaction between farm and breed was significant for Vaccinium myrtillus $(P<0.05)$ and the plant group "total grass" $(P<0.01)$. When testing the two study sites separately, no significant effect of breed was found at Skåbu. However, in Valdres, NRF had significantly $(P<0.05)$ more fragments of Vaccinium myrtillus than STN, and STN had a tendency $(P=0.060)$ of more Nardus stricta fragments than NRF.

Figure 3 illustrates the LS-means in observed fragments for the breeds by farm, indicating tendencies to interaction for the plant group "Total grass species", the plant species Vaccinium myrtillus and Nardus stricta, and finally the plant genera Carex spp. These illustrations are chosen because they together contribute to a picture of possible differences in plant and vegetation preferences of the two breeds STN and NRF.

\section{DISCUSSION}

\subsection{Possible breed differences in plant and vegetation preferences}

This study intended to study if different selection history for high milk production in two cattle breeds influences the animals' plant and vegetation preferences in a way that affects the management of the biodiversity in semi-natural grasslands.

In general, semi-natural mountain grasslands are regarded as extensive grazing areas, in the meaning that the animals must make more of an effort when searching for fodder that will satisfy their hunger and nutrient requirements. This is in contrast to grazing on cultivated pastures where the plant species are carefully selected to give the grazers easy access to fodder with a high nutrient value. The semi-natural mountain grasslands in this study are characterised by great diversity of vegetation types and plant species, enabling the animals to choose which vegetation they prefer to graze. Only the vegetation types that were actually grazed by the cows are described and mentioned in this study, and they are all valuable grazing areas [32].

The distribution of species within the grasslands and the representation in the faeces samples are more uniform in Skåbu than in Valdres (Tab. V). Furthermore, the present study shows some tendencies of differences in plant and vegetation preferences of the two breeds STN and NRF (Fig. 3, Tab. V). Differences in observed plant fragments in faeces samples from plant species, plant genera and plant 
Table V. Results from the statistical analyses on the plant fragment residues observed in the faeces samples. The figures for the plant species, plant genera and plant groups are given as percentage of total fragments. The figures for "total fragments" and "total fibres" are actual findings. Figures in bold print are significant values.

\begin{tabular}{|c|c|c|c|c|c|c|c|c|}
\hline \multirow{2}{*}{$\begin{array}{l}\text { Plant species, } \\
\text { genera or } \\
\text { group }\end{array}$} & \multirow{2}{*}{ Farm } & \multirow{2}{*}{ Breed } & \multirow{2}{*}{ Month } & \multirow{2}{*}{$\begin{array}{l}\text { Interaction } \\
\text { Farm/breed }\end{array}$} & \multicolumn{2}{|c|}{ LS-means } & \multicolumn{2}{|c|}{ LS-means } \\
\hline & & & & & STN & NRF & Skåbu & Valdres \\
\hline \multicolumn{9}{|l|}{ Blueberry } \\
\hline Vaccinium & $* *$ & & & $*$ & & & & \\
\hline $\begin{array}{l}\text { myrtillus } \\
\text { Heather }\end{array}$ & & & & & 1.84 & 2.09 & 2.63 & 1.29 \\
\hline Calluna & $* *$ & & & & & & & \\
\hline vulgaris & & & & & 1.93 & 2.06 & 3.16 & 0.83 \\
\hline $\begin{array}{l}\text { Tufted hair- } \\
\text { grass }\end{array}$ & ** & & & & & & & \\
\hline $\begin{array}{l}\text { Deschampsia } \\
\text { cespitosa }\end{array}$ & & & & & 26.99 & 25.13 & 19.25 & 32.87 \\
\hline $\begin{array}{l}\text { Wavy } \\
\text { hairgrass }\end{array}$ & $* *$ & & $* *$ & & & & & \\
\hline \multicolumn{9}{|l|}{ flexиosa } \\
\hline Red fescue & $* *$ & & & & & & & \\
\hline Festuca rubra & & & & & 0.42 & 0.43 & 4.10 & 1.55 \\
\hline Unidentified & $* *$ & & & & & & & \\
\hline fescue & & & & & 6.32 & 7.86 & 8.96 & 5.23 \\
\hline \multicolumn{9}{|l|}{ Festuca spp. } \\
\hline Meadow grass & $*$ & & $* *$ & & & & & \\
\hline Poa spp. & & & & & 3.80 & 2.95 & 2.79 & 3.96 \\
\hline Bent grass & $*$ & & $* *$ & & & & & \\
\hline Agrostis spp. & & & & & 2.76 & 2.70 & 3.29 & 2.17 \\
\hline Matgrass & $* *$ & * & & & & & & \\
\hline Nardus stricta & & & & & 5.08 & 3.76 & 1.69 & 7.15 \\
\hline $\begin{array}{l}\text { Unidentified } \\
\text { grass }\end{array}$ & $* *$ & & & & 12.91 & 12.95 & 11.46 & 14.40 \\
\hline \multicolumn{9}{|l|}{ Graminae } \\
\hline Sedge species & ** & & & & & & & \\
\hline \multirow[t]{2}{*}{ Carex spp. } & & & & & 8.39 & 9.47 & 4.41 & 13.45 \\
\hline & ** & & & & & & & \\
\hline \multirow[t]{2}{*}{ Herbs } & & & & & 7.66 & 7.53 & 11.69 & 3.50 \\
\hline & $* *$ & & & $* *$ & & & & \\
\hline \multirow[t]{2}{*}{ Total grass } & & & & & 77.68 & 75.80 & 74.04 & 79.43 \\
\hline & ** & & * & & & & & \\
\hline Total Festuca & & & & & 9.17 & 10.66 & 13.35 & 6.49 \\
\hline \multicolumn{9}{|l|}{ Total } \\
\hline fragments & & & & & 232 & 229 & 227 & 235 \\
\hline & & & $* *$ & & & & & \\
\hline Total fibers & & & & & 312 & 333 & 334 & 312 \\
\hline
\end{tabular}

$* * 1 \%, * 5 \%$. 
Total grass species
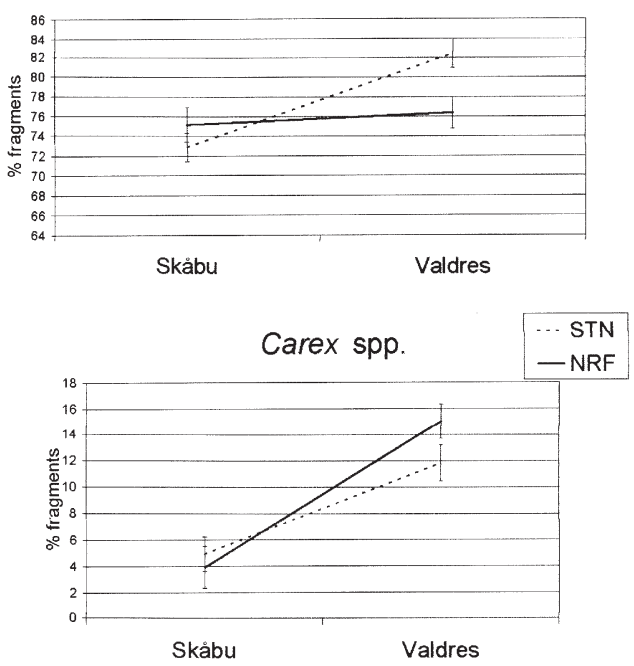

Vaccinium myrtillus

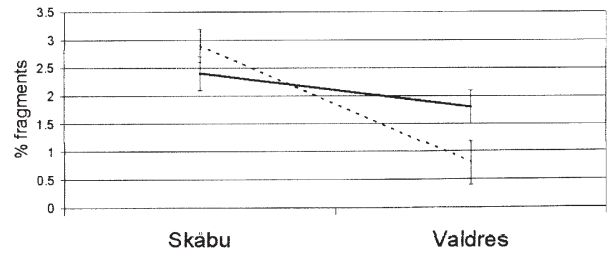

Nardus stricta

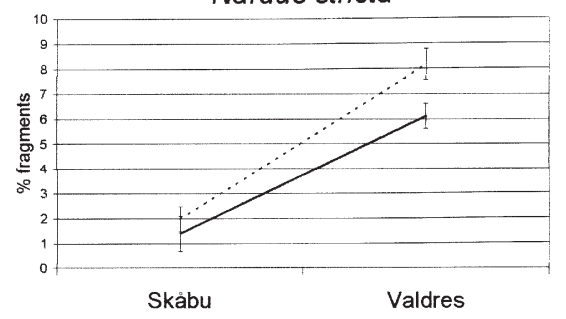

Figure 3. Illustrations of LS-means in observed fragments for the breeds by farm for four of the tested plant species/genera/groups. Relevant $P$-values: Total grass species: interaction between farm and breed $(P=0.010)$, Vaccinium myrtillus: interaction between farm and breed $(P=0.036)$, breed difference in Valdres $(P=0.038)$, Nardus stricta: breed difference when farms are tested together $(P=0.052)$, tendency to breed difference in Valdres $(P=0.060)$, Carex spp.: tendency to interaction between farm and breed $(P=0.115)$. There are significant differences between farms $(P<0.01)$ for all four plant species/genera/groups.

groups are available indicators of possible differences of chosen vegetation types between the two breeds. Since the herds to a certain extent spread while grazing and the patches of the different vegetation types might be rather local, the cows still have the possibility to choose different vegetation types and plant species if they desireeven if grazing in herds.

The results presented in Figure 3 indicate that when grazing in areas with quite nutrient- and base-rich soil and speciesrich vegetation types, as in Skåbu, the two breeds graze the same vegetation and plant species. In Valdres, however, where the soil is less fertile, the plant species diversity is lower and the plant species distribution less uniform than in Skåbu, the results indicate that the NRF cows graze more in patches where Carex spp. grow than the STN cows. STN also graze more
Carex spp. in Valdres than in Skåbu, but the increase is less than for NRF. Both breeds graze less Vaccinium myrtillus in Valdres, but since NRF decrease less than STN and since Vaccinium myrtillus occur in the same vegetation type as Carex spp. in Valdres, this indicates that NRF cows graze more in patches where Carex spp. grow and Vaccinium myrtillus occur. Both breeds graze more Nardus stricta in Valdres than in Skåbu, but STN has a higher increase than NRF, indicating that the STN cows graze more in nutrient poor areas where Nardus stricta is common in Valdres than NRF.

\subsection{Nutrient value as an indication of different vegetation preferences}

The results from the statistical analysis show significant interaction between 
breed and farm for the plant group "total grass species". Figure 3 shows that both breeds graze more grass in Valdres than in Skåbu, however, STN increases its amount of fragments from grass more than NRF - thus giving rise to the question: What do NRF cows eat in Valdres? The only analysed plant species/genus that gives a corresponding picture to the interaction between farm and breed for "total grass species" is the Carex spp. genus. The content of Carex spp. in the faeces samples, which was around $12-14 \%$ in Valdres, indicates that the cows selectively grazed these species, probably at the expense of grass species. Thus, the tendency of replacing grass with Carex spp. seems to be higher in NRF than STN. The nutrient poorer soil conditions and the lower plant species diversity in Valdres may explain NRF's preferences to Carex spp. at the expense of grass, since Carex spp. compared to grass have a better nutrient value $[16,17]$. In addition Carex spp. are more common species, and thereby more available, in Valdres than in Skåbu.

Vaccinium myrtillus is recorded with just about $2 \%$ in the faeces samples. Earlier studies [5, 43] have shown that Vaccinium myrtillus is grazed only in small amounts compared to grasses. The low percentage may indicate that it is not deliberately grazed, but eaten almost by accident when grazing surrounding vegetation. The significant differences between breeds for fragments of Vaccinium myrtillus in Valdres may support the conclusion that NRF grazes more in vegetation where Carex spp. grows than STN, since Vaccinium myrtillus also occurs in such plant communities.

The differences between the breeds, independent of study site, are significant only for Nardus stricta (Tab. V). The STN breed has the highest share of fragment residues of this species. As mentioned earlier, Nardus stricta is not regarded as a valuable or nutrient rich grass species, its only advan- tage in vegetation types as $\mathrm{G} 4 \mathrm{c}$ and $\mathrm{G} 5 \mathrm{~b}$ is that it is very common and thereby easily accessible. When STN graze this species more than NRF, it might be an expression of not being so concerned about grazing the most nutrient rich vegetation, simply because the breed's nutrient requirements are still satisfied when grazing vegetation with relatively high shares of Nardus stricta.

\section{CONCLUSION}

This study shows that a cattle breed selected for high yield, thus having a higher demand for nutrient rich fodder, seems to prefer to graze the most nutrient rich species (i.e. preferring Carex spp. over grass species) compared to a lower yielding cattle breed, when grazing on shared, not especially nutrient, base or species rich grasslands.

When grazing semi-natural mountain grasslands, the lower yielding cattle breed Blacksided Trønder and Nordland Cattle (STN) grazes significantly more Nardus stricta, a less nutrient rich grass species, than the moderate yielding cattle breed Norwegian Red (NRF).

When managing semi-natural grasslands, the effect of grazing the vegetation might be different when choosing a low instead of a moderate yielding dairy cattle breed. This possible difference ought to be taken into consideration since loss of biodiversity by re-growth of less nutrient rich vegetation types seems to be smaller when using a lower yielding breed.

\section{ACKNOWLEDGEMENTS}

We would like to thank the farmers at Brenden and Skogstadstølen summer farms for placing their herds at disposal for this study and the two technicians, Jørn Skoe and Christoffer A. Aalerud, that conducted the field work 
in the unsheltered, and sometimes very wet, highlands. Furthermore, we owe Brita Dahlberg many thanks for excellent analyses of the faeces samples. This study was part of a project financed by the Nordic Gene Bank Farm Animals and the Research Council of Norway. We would like to thank both institutions for supporting this project.

\section{REFERENCES}

[1] Aglen V.A., Stensgård M., Atferdsforskjeller hos NRF-kyr selektert for høg og lav mjølkeavdrått [Behaviour differences between NRF cows selected for high and low milk yield], Master degree at Department of Animal and Aquaculture Science, Agricultural University of Norway, 1994.

[2] Aune B., Temperaturnormaler, normalperioden 1961-1990 [Temperature normals in the norm period 1961-1990], in: Klima - DNMI Report, No. 2, 1993.

[3] Austrheim G., Plant biodiversity and land use in sub alpine grassland. A conservation biological approach, Dr. Scient. Thesis, Dept. of Botany, NTNU Trondheim, 1998.

[4] Beilharz R.G., Quantitative genetics and evolution: Is our understanding of genetics sufficient to explain evolution? J. Anim. Breed. Genet. 110/3 (1993) 161-170.

[5] Bjor K., Graffer H., Beiteunders $\varnothing$ kelser i skogsmark [Grazing Studies in the Woodlands], Res. Exp. in Agric. 14 (1963) 121-365.

[6] Braastad B.O., Kathle J., Behavioural differences between laying hen populations selected for high and low efficiency of food utilisation, Brit. Poultry Sci. 30 (1989) 533-544.

[7] Bryn A., Norderhaug A., Daugstad K., Regrowth effects on vascular plant richness in Norwegian, abandoned summer farm areas, Ann. Iceland. For. (2001).

[8] Direktoratet for naturforvaltning, Verdifulle kulturlandskap i Norge. Mer enn bare landskap! [Directorate for Nature Management, Valuable Cultural Landscapes in Norway. More than only landscapes!], Final report, 1994.

[9] Direktoratet for naturforvaltning, Nasjonal rødliste for truete arter i Norge 1998 [Directorate for Nature Management, National red list for threatend species in Norway], DN-report, Vol. 3, 1999.
[10] Ekstam U., Forshed N., Svenska naturbetesmarker - historia og ekologi [Swedish natural grasslands - history and ecology], Swedish Environmental Proteciton Agency, Stockholm, 2004.

[11] Emanuelsson U., Johansson C.E. (Eds.), Biotopvern i Norden. Biotoper i det nordiska kulturlandskapet [Biotope Conservation in the Nordic Countries. Biotopes in the Nordic Cultural Landscape], Nordic Council of Ministers, Environmental Report, Vol. 6, 1987.

[12] Fremstad E., Vegetasjonstyper i Norge [Vegetation types in Norway], Norwegian Institute for Nature Research, NINA Topic 12, 1997, pp. 1-279.

[13] Fremstad E., Moen A. (Eds.), Truete vegetasjonstyper i Norge [Threatend vegetation types in Norway], Norwegian University of Science and Technology, Museum of Natural History and Archaeology, Botanical Series, Report 4, 2001, pp. 1-231.

[14] Førland E.J., Nedbørnormaler, normalperiode 1961-1990 [Precipitation normals, norm period 1961-1990], Climate - Report from Norwegian Meteorological Institute, No. 39, 1993.

[15] Garcia-Gonzales R., L'emploi des épidermis végétaux dans la détermination du régime alimentaire de l'isard dans les Pyrénées occidentales, Documents d'Écologie Pyrénéenne 3, 4 (1984) 307-313.

[16] Garmo T.H., Chemical composition and in vitro digestibility of indigenous mountain pasture plants in different plant groups (Preliminary report), Rangifer 6 (1986) 14-22.

[17] Garmo T.H., Utmarksbeite til geit. [Rough grazing for goats], in: Drabløs D. (Ed.), Geitboka, Landbruksforlaget, Oslo, 1987, pp. 101-109.

[18] Heje K.K., Håndbok for jordbruket [Agricultural Handbook], Landbruksforlaget, Oslo, 2000, 107 p.

[19] Ihse M., Blom G., Monitoring changes in land-use, landscape features, biodiversity and cultural heritage in Sweden- the LIMproject, in: Jongman R.H.G., Mander U. (Eds.), Consequences of Land Use Changes, WITT Press, Southhampton and Boston, series Advances in Ecology, 2000, pp. 39-74.

[20] Inglis I.R., Forkman B., Lazarus J., Free food or earned food? A review and fuzzy model for contrafreeloading, Anim. Behav. 53 (1997) 1171-1191.

[21] Kathle J., Behavioural differences between two white egg hybrids in aviary, 6th World 
Congress on Genetics Applied to Livestock Production, Armidale, Australia, Vol. 27, 1998, pp. 389-392.

[22] Körner C., Alpine plant life. Functional plant ecology of high mountain ecosystems, Springer Verlag, Berlin, 1999.

[23] Kvamme M., Berge J., Kaland P.E., Vegetasjonshistoriske unders $ø$ kelser i NysetSteggjevassdraget [Study of the history of vegetation in the river system NysetSteggjevassdraget], Archeological report 17, Historical Museum, Bergen, 1992.

[24] Lid J., Lid D.T., Norsk flora. [The Norwegian Flora], 7th ed., Reidar Elven (Ed.), 2005.

[25] Lindqvist C.E.S., Schutz K.E., Jensen P., Red jungle fowl have more contrafreeloading than white leghorn layers: Effect of food deprivation and consequences for information gain, Behaviour 139 (2002) 1195-1209.

[26] Lutro O., Tveten E., Geologisk kart over Norge, berggrunnskart ̊̊rdal M 1:250 000 [Geological maps of Norway, bedrock map Årdal M 1:250 000], Geological Survey of Norway, 1996.

[27] Moen A., National Atlas of Norway: Vegetation, Norwegian Mapping Authority, Hønefoss, 1999, 200 p.

[28] Norderhaug A., Austad I., Hauge L., Kvamme M. (Eds.), Skjøtselsboka for kulturlandskap og gamle norske kulturmarker [The book of management for cultural landscapes in Norway], Landbruksforlaget, Oslo, 1999.

[29] Norderhaug A., Ihse M., Kulturlandskapsutviklingen i Norden 1975-2000 et forsøk på oppsummering, in: Austad I., Hamre L.N., Ådland E. (Eds.), Gjengroing av kulturmark. Kulturlandskapet ved tusenårsskiftet [The development of the cultural landscape in the Nordic Countries 1975-2000 - an attempt to summarize, in: Regrowth of semi-natural vegetation types. The cultural landscape by the turn of the milennium], Report from a Nordic seminar for researchers in Sogndal, 15-18 September 2001, The Museum of Bergen, Publication No. 12, 2003, pp. 7-12.

[30] Rauw W.M., Kanis E., Noordhuizen-Stassen E.N., Grommers F.J., Undesirable side effects of selection for high production efficiency in farm animals: a review, Livest. Prod. Sci. 56 (1998) 15-33.

[31] Rauw W.M., Luiting P., Bakken M., Schuurman T., de Veer C.J.M., Vangen O., Behavioural differences in non-reproductive adult females in a long term selection ex- periment for litter size in mice, Appl. Anim Behav. Sci. 66 (2000) 249-262.

[32] Rekdal Y., Husdyrbeite i fjellet - vegetasjonstypar og beiteverdi [Grazing land in the mountains for farm animals - vegetation types and grazing value], The Norwegian Institute of Land Inventory (NIJOS), Report 7/01, 2001

[33] Resvoll-Holmsen H., Fra fjeldskogene i det østenfjeldske Norge [From the mountain forests in the eastern part of Norway], J. Forest. (1918).

[34] Rook A.J., Tallowin J.R.B., Grazing and pasture management for biodiversity benefit. A review, Anim. Res. 52 (2003) 181-189.

[35] Sakshaug B., Årbok for beitebruk i Norge 1932-1933 XI [Annual for Pasture Usage in Norway 1932-1933 XI], Royal Norwegian Society for Development, 1934

[36] Schutz K.E., Jensen P., Effects of resource allocation on behavioural strategies: A comparison of red jungleflow (Gallus Gallus) and two domesticated breeds of poultry, Ethology 107 (2001) 753-765.

[37] Sickel H., Ihse M., Norderhaug A., Sickel M., How to monitor semi-natural key habitats and grazing preferences of cattle in mountain summer farming areas. An aerial photo and GPS method study, Landscape Urban Plan. 67 (2004) 67-77.

[38] Siedlecka A., Nystuen J.P., Englund J.O., Hossack J., Lillehammer berggrunnskart M 1:250 000 [Bedrock map Lillehammer, M 1:250 000], Geological Survey of Norway, 1987.

[39] Statistics Norway, Table Cattle and sheep. No of heads as per 1 January, by county, http://www.ssb.no/english/subjects/10/04/10/ jordhus_en/tab-2006-05-09-02-en.html.

[40] Sæther N.H., Vangen O., Motives for utilizing the Blacksided Trønder and Nordland: A native cattle breed in Norway, Anim. Genet. Res. Inform. 31 (2001) 15-26.

[41] Sæther N.H., Bøe, K, Vangen O. Differences in grazing behaviour between a high and a moderate yielding Norwegian dairy cattle breed grazing semi-natural mountain grasslands, Acta Scand., Sect. A, Anim. Sci. (2006) in press.

[42] TINE Produsentrådgiving, statistikksamling [TINE Advisory Service - Producers], Statiscal Collection 2002.

[43] Vigerust Y., Fjellbeitene i Sikilsdalen. Årbok for beitebruk i Norge 1946-1947 [The Mountain Pastures in Sikilsdalen. Annual for Pasture Usage in Norway 1946-1947], Roy. Norweg. Soc. Dev. 18 (1949) 18-188. 